EASTERN EUROPE SINCE 1945 


\section{The Making of the Modern World}

Series Editor: Geoffrey Warner

Published
Geoffrey Swain and Nigel Swain Eastern Europe Since 1945, 2nd edition

Forthcoming

Mark Roseman Germany Since 1945

John Simmonds France Since 1945 


\title{
EASTERN EUROPE SINCE 1945
}

\author{
SECOND EDITION
}

\section{Geoffrey Swain}

Professor of European History

University of the West of England

and

Nigel Swain

Lecturer in History and

Deputy Director of the Centre for Central and East European Studies

University of Liverpool 
(C) Geoffrey Swain and Nigel Swain 1993, 1998

Softcover reprint of the hardcover 2nd edition 1998 978-0-333-73233-5

All rights reserved. No reproduction, copy or transmission of this publication may be made without written permission.

No paragraph of this publication may be reproduced, copied or transmitted save with written permission or in accordance with the provisions of the Copyright, Designs and Patents Act 1988, or under the terms of any licence permitting limited copying issued by the Copyright Licensing Agency, 90 Tottenham Court Road, London W1P 9HE.

Any person who does any unauthorised act in relation to this publication may be liable to criminal prosecution and civil claims for damages.

The authors have asserted their rights to be identified as the authors of this work in accordance with the Copyright, Designs and Patents Act 1988.

First published 1993

Second edition published 1998

MACMILLAN PRESS LTD

Houndmills, Basingstoke, Hampshire RG21 6XS

and London

Companies and representatives throughout the world

ISBN 978-0-333-73234-2

DOI 10.1007/978-1-349-27069-9

A catalogue record for this book is available from the British Library.

This book is printed on paper suitable for recycling and made from fully managed and sustained forest sources.

$\begin{array}{llllllllll}10 & 9 & 8 & 7 & 6 & 5 & 4 & 3 & 2 & 1\end{array}$

$\begin{array}{llllllllll}07 & 06 & 05 & 04 & 03 & 02 & 01 & 00 & 99 & 98\end{array}$

Published in the United States of America 1998 by

ST. MARTIN'S PRESS, INC.,

Scholarly and Reference Division,

175 Fifth Avenue, New York, N.Y. 10010

ISBN 978-0-312-21690-0 
To our parents 
I believed in communism. For me, communism was freedom. That was my mistake. Absolute freedom doesn't exist, especially not in communism, but if I hadn't believed this I wouldn't have become a communist. Of course the quest for such freedom leads to revolution, violence, overthrowing the ruling classes, the long transformation of society by education. But I was convinced that in the end this process was moving towards more and more freedom, no end to this freedom.

Milovan Djilas, January 1992 


\section{CONTENTS}

List of Tables

1 Revolution in Eastern Europe

2 Different Roads to Socialism

3 An End to Diversity

4 1956: Communism Renewed?

5 Actually Existing Socialism in Operation

6 Reform Communism or Economic Reform

7 Neo-Stalinism Triumphant

8 The Fall of Actually Existing Socialism

9 Adapting to Capitalism: Consensus or Confrontation? 


\section{LIST OF TABLES}

5.1 The creation of the Soviet-type planning system in Eastern Europe

5.2 Land reform and collectivisation in post-war Eastern Europe

5.3 Socialised share of industrial output and retail turnover, 1952

5.4 Share of net material product devoted to accumulation (net investment in fixed capital plus increases in inventories) and personal consumption (\%)

5.5 Share of investment by branch, 1953-5 (Comecon countries gross investment, Yugoslavia net investment in fixed assets)

5.6 Index of GDP and energy intensity of GDP, 1973 (United States $=100$ )

5.7 Constitutional arrangements in Eastern Europe 106

5.8 Minor political parties in Eastern Europe

5.9 Full name of Communist Party and Party leader's non-Party post, 1980-1

6.1 National income, 1956-65 (percentage annual rates of growth of net material product) 


\section{Chronology}

1 April 1939

23 August 1939

3 September 1939

22 June 1941

May 1943

June 1944

July 1944

23 August 1944

end August 1944

5 September 1944

9 September 1944

1 October 1944

November 1944

December 1944

5January 1945

February 1945

end February 1945

March 1945

April 1945

8 May 1945
Final defeat of the Republican Government during the Spanish Civil War.

Nazi-Soviet Pact: East European Communist Parties adopt new revolutionary programme.

Start of Second World War.

Nazis invade Soviet Union: Balkan Communist Parties start insurrections.

Dissolution of the Comintern.

British Government recognises Tito's Communist government.

Red Army crosses into Poland: National Liberation Committee established.

King Michael's coup in Romania: formation of coalition government.

Stalin's decision to support Bulgarian insurrection.

Soviet Union declares war on Bulgaria.

Communist coup in Bulgaria.

Red Army crosses into Hungary.

Start of civil war in Poland lasting until summer 1945.

British suppress communist insurrection in Greece. Stalin recognises Communist government in Poland.

Yalta Conference: decision to form National Unity Government in Poland.

Stalin supports Communist coup in Romania.

Stalin shelves plans for Balkan Federation after Allied protests.

Liberation of Czechoslovakia.

End of Second World War. 
August 1945

4 November 1945

11 November 1945

18 November 1945

2 December 1945

26 May 1946

30 June 1946

27 October 1946

19 November 1946

19 January 1947

February 1947

March 1947

May 1947

June 1947

10 July 1947

30 August 1947

end September 1947

27 November 1947

December 1947

end February 1948

1 March 1948

July 1948

May 1949

September 1949

November 1949

December 1949
Potsdam Conference: agreement on conditions for signing peace treaties with Hungary, Bulgaria and Romania.

Hungarian elections.

Yugoslav elections.

Bulgarian elections (boycotted by opposition candidates).

Albanian elections.

Elections in Czechoslovakia.

Polish referendum.

Bulgarian elections in which opposition takes part.

Romanian elections.

Polish elections.

Truman doctrine; American commitment to anticommunist cause in Greece.

Stalin's support for Yugoslavia's role in Greece.

Communists excluded from government in France and Italy.

Marshall Plan announced.

Stalin instructs Czechoslovak government to reject Marshall Aid.

Hungarian elections.

Foundation of Cominform.

New revolutionary stance adopted by Czechoslovak communists.

Diplomatic offensive launched by Yugoslavia.

Increased aid for Greek communists.

Communist coup in Czechoslovakia. Start of StalinTito dispute.

Yugoslavs decide to resist Stalin's demand that they join a Balkan Federation dominated by Bulgaria and Albania.

Yugoslavia expelled from the Cominform.

Cominform countries adopt 'soviet' model of industrial planning and collectivised agriculture.

Trial of Koçi Xoxe.

Trial of László Rajk.

Cominform denounces Yugoslav regime: diplomatic relations broken off.

Trial of Traicho Kostov. 
June 1950

November 1952

6 March 1953

15 June 1953

end June 1953

16 January 1954

23 October 1954

February 1955

March 1955

26 May 1955

February 1956

April 1956

18 April 1956

20 June 1955

end June 1956

18 July 1956

19 September 1956

19 October 1956

23 October 1956

24 October 1956

30 October 1956

2 November 1956
Yugoslavs establish workers' self-management.

Trial of Rudolf Slánský.

Yugoslav Communist Party renamed League of Communists.

Death of Stalin.

Restoration of diplomatic relations between Soviet Union and Yugoslavia.

Brioni plenum of Yugoslav Party ends reform programme. New Hungarian Prime Minister Imre Nagy introduces 'new course'.

Milovan Djilas disciplined for writing that the Leninist Party was obsolete.

Patriotic People's Front founded in Hungary.

Khrushchev replaces Malenkov in Soviet Union.

Nagy deposed in Hungary.

Khrushchev's rapprochement with Tito: inter-state relations restored.

Khrushchev denounces Stalin at XXth Party Congress.

New leadership in Poland and other East European states.

Cominform abolished.

Khrushchev's rapprochement with Tito: party relations restored.

Riots in Poznan.

Rákosi dismissed at Soviet request.

Poles cautioned not to relax discipline.

Start of over three weeks of talks between Khrushchev and Tito.

Polish Party Plenum restores Gomułka to leadership: mobilised working class frustrates plans for Soviet armed intervention.

Demonstrations mark start of Hungarian revolution.

Soviet troops intervene in Hungary.

Nagy forms multi-party government: the next day opens talks seeking the withdrawal of Hungary from the Warsaw Pact.

Khrushchev and Tito agree to intervene in Hungary. 
4 November 1956

15 November 1956

November 1957

April 1958

May 1958

Late 1958

January 1959

April 1961

13 August 1961

October 1961

August 1962

Early 1963

July 1963

September 1963

July 1964

October 1964

July 1965

July 1966

March 1968

January 1968

June 1968

20-1 August 1968

1970-1

December 1970

May 1971
Soviet intervention resumes.

Soviet-Polish agreement on the stationing of Soviet troops in Poland.

Conference of Ruling Communist Parties fails to restore unity to communist movement.

Yugoslav League of Communists adopts a programme asserting its unique road to socialism.

Meeting of the Political Consultative Committee of the Warsaw Pact Announcement that Soviet troops will withdraw from Romania.

Renewed collectivisation drive.

XXIst Congress of the Soviet Party.

Soviet Union cancels aid to Albania.

Building of Berlin Wall.

XXIInd Congress of the Soviet Party.

Second de-Stalinisation campaign.

Beginnings of Sino-Soviet split.

New emphasis on economic development and catching up with the West.

Kádár: 'Those who are not against us are with us' in Hungary.

'Revolt of the intellectuals' in Czechoslovakia.

Plans for a greater degree of Comecon integration abandoned because of Romanian opposition.

GDR decides to implement the New Economic System throughout the economy.

Hungarian Central Committee accepts the principles of the New Economic Mechanism.

Khrushchev replaced by Brezhnev.

Yugoslavia's second economic reform.

Reformists secure the dismissal of Rankovic in Yugoslavia.

Student demonstrations in Poland.

Dubček replaces Novotný as Czechoslovak Party leader.

Student demonstrations in Yugoslavia.

Soviet invasion of Czechoslovakia.

Croat nationalist unrest in Yugoslavia.

Price increases in Poland lead to 'Baltic Crisis'.

Honecker replaces Ulbricht in GDR. 
September 1971

November 1972

December 1972

August 1975

June 1976

September 1976

January 1977

July 1978

July 1980

August 1980

13 December 1980

March-April 1981

1982

July 1983

March 1985

October 1987

August 1988

June 1989

August 1989

September 1989

9 November 1989

November 1989

December 1989

21 December 1989

25 December 1989 January 1990
Four Power Agreement on Berlin.

Measures partially recentralising the economy approved by Central Committee in Hungary.

Basic Treaty between GDR and German Federal Republic.

Helsinki Final Act.

Price increases in Poland result in strikes and demonstrations.

Foundation in Poland of the Committee for the Defence of Workers (KOR).

Foundation of Charter 77 in Czechoslovakia.

China suspends foreign aid to Albania.

Price increases in Poland.

Solidarity free trade union founded in Poland.

Martial law declared in Poland.

Ethnic disturbances in Kosovo.

Debt crisis in Yugoslavia.

'Small business reform' in Hungary.

Martial law lifted in Poland.

Gorbachev becomes General Secretary of Central Committee of CPSU.

Slobodan Milošević becomes leader of Serbian League of Communists.

Polish government decides to negotiate with Solidarity.

Elections in Poland. Solidarity wins vast majority of seats available to it.

Solidarity-led government formed in Poland.

Hungary allows GDR citizens to emigrate via Austria. Government and Opposition Round Table Talks concluded.

Berlin Wall breached.

Demonstrations in Prague. Zhivkov resigns in Bulgaria.

Government of National Understanding formed in Czechoslovakia.

Ceauşescu rally disrupted. Fighting between demonstrators and security police.

Nicolae and Elena Ceauşescu executed.

Poland implements Balcerowicz 'shock therapy' programme. 
March-April 1990 Elections in Hungary. Right-of-centre coalition April 1990

April-May 1990

May 1990

June 1990

1 July 1990

3 October 1990

November-

December 1990

December 1990-

January 1991

April 1991

June 1991

28June 1991

1 July 1991

June-July 1991

September 1991

October 1991 government led by Hungarian Democratic Forum. Elections in Slovenia (won by DEMOS coalition). Elections in Croatia (won by nationalistic Croatian Democratic Union).

Elections in Romania (won by National Salvation Front which is dominated by former communists). Elections in Czechoslovakia (won by Civic Forum and Public Against Violence).

Elections in Bulgaria (won by the former communist party).

Miners break up opposition demonstration in Romania.

German currency union.

Germany reunified.

Presidential elections in Poland (Wałęsa elected).

Communist-led government in Bulgaria resigns following strike wave.

Elections in Macedonia, Bosnia-Hercegovina, Serbia and Montenegro. Former communists win in Serbia and Montenegro. Weak coalition government in Bosnia and Hercegovina. Nationalist coalition in Macedonia.

Anti-government demonstrations in Albania.

Elections in Albania (won by former communists). Albanian communist-led government resigns after strike-wave.

Comecon formally dissolved.

Warsaw Pact formally dissolved.

Slovenia established de facto independence after brief hostilities.

Relations between Croatia and Serbia degenerate to fighting. UN imposes peace of sorts.

Romanian government resigns after demonstrations led by miners. Broad-based interim government formed.

Elections in Poland (no clear winner). Elections in Bulgaria (won by Union of Democratic Forces with small majority). 
December 1991

26 December 1991

15 January 1992

March 1992

June 1992

October 1992

May 1993

March 1994

May 1994

September 1994

November 1995

June 1996

November 1996

December 1996

Spring 1997

May 1997

June 1997

September 1997
Albanian Democratic Party withdraws support from coalition government.

Soviet Union formally dissolved, following Gorbachev's resignation on Christmas Day.

The European Community recognises the independence of Slovenia and Croatia and hence the break-up of Yugoslavia.

Bosnian War starts.

Elections in Albania bring Democratic Party to power. Romanian elections give victory to anti-reform President Iliescu.

Elections in Czechoslovakia result in decision to dissolve state into Czech Republic and Slovakia. Fall of UDF government in Bulgaria.

Former communists and allies return to power in Poland.

Prime Minister Meciar temporarily loses power in Slovakia, returns to power in December after October elections.

Former communists return to power in Hungary.

Socialists return to power in Bulgaria.

Wałęsa replaced as Polish president by former communist.

Dayton Accord ends the Bosnian War.

Conservative government in Czechoslovakia loses overall majority, banking crisis follows.

Disputed election in Albania returns Democratic party to power.

Reformists win Romanian elections.

Widespread demonstrations in Serbia against President Milošević.

Collapse of socialist government in Bulgaria and return of the UDF to power.

Albania descends into anarchy after pyramid selling crisis, foreign troops restore order.

Demonstrations in Slovakia after collapse of presidential referendum.

Czech Republic faces financial crisis.

Socialists win Albanian election.

Former communists lose power in Polish elections. 